\title{
Does Strategic Leadership Support Organizational Commitment: Evidence from Islamic Banks in Kuwait
}

\author{
SALAH A. AlabDULJADER \\ Department of Management and Marketing,College of Businesses Administration, \\ Kuwait University, KUWAIT
}

\begin{abstract}
The need for loyal strategic leadership has never been more important than it is today. The twenty-first century requires - as no other century has ever imposed - on the leaders of organizations to create strategic awareness and dynamic renewed processes, in order to ensure strategic consistency. From that point, current study aimed at examining the influence of strategic leadership on developing organizational commitment within Islamic banks in Kuwait. Quantitative approach was adopted depending on a questionnaire that was distributed on (273) employees within Islamic banks in Kuwait. With an R value of (.817) results of study indicated an influence of strategic leadership on organizational commitment through its impact from a managerial perspective which scored an $\mathrm{R}$ value of (.769) and ethical perspective with an $\mathrm{R}$ value of (.495). Study recommended promoting strategic leadership practices by investing in human capital and focusing on continuous learning and improvement.
\end{abstract}

Key-Words: - Strategic leadership, Long-term Goals, Leaders, Commitment, Turnover, Job Satisfaction, Learning, Human Capital, Organizational Culture.

Received: September 19, 2020. Revised: March 9, 2021. Accepted: April 2, 2021.Published: April 8, 2021.

\section{Introduction}

Some relevant studies can be found in [31] and [30] argued that on a broad sense, leadership is responsible for the development of countries, as well as leadership is questionable for the development of organizations within countries as they are able to utilize human workforce and other resources with high efficiency and effectiveness. We may see countries that have the financial and human resources, but at the same time, they lack leadership experience which can be seen as an obstacle in their development [21]. There is no doubt that the success of economic and social enhancements and achieving goals can only be acquired by making good use of the available material and human resources, as well as the success of resources in the society [12]. It is out of question that the use of the resources without waste is connected to the adequacy of leadership in different areas, and the success of projects and reaching the needed objectives outlined in the work strategy depends on the suitability of the leadership systems.

From that, we can say that leadership is the ability to influence others and arouse their enthusiasm in order to achieve a specific goal [13]. It is also known - [7] - as the activity practiced by the administrative leader in the field of making and issuing decisions, issuing orders, and administrative supervision of others using official authority and by influencing and appealing with the aim of achieving a specific goal .

Leadership was also defined as the ability of leaders to gain approval from others, while leadership was defined as the ability to impact others, orient them and organize their efforts, in addition to influencing their behavior so as to achieve the previously set goals and objectives. Generally speaking, leadership is a set of standards and principles that if applied - has the ability to reach aims determined within internal plans of an organization [5]; [14].

All organizations need guidance and goals' setting, in addition to policies and plans in order to have the well and the power to achieve such goals. Also, along the enhanced environment of business; organizations became more intact with the need for the creation of aims and their application is built on examining available resources and assessing the internal and external environment which can be reached through adopting strategic leadership [1].

The multiple definitions and variables of strategic leadership have made impossible to set on a certain definition for strategic leadership, not to mention the level of diverse functions it performs. Among the prominent definitions of strategic leadership is that it refers to a newly leadership style which contributes in enhancing and developing organizational effectiveness within a short period of time [15]. Strategic leader can deduce reality as an approach to develop a future vision that is able to be 
formulated into actions, in addition to motivate abilities, talents, and strategic experiences which can frame a better environment for employees to be innovative and creative. Strategic leadership is a leadership style that brings a future vision formulated in a framework of development, excellence, and success, this framework is bound to the level of strategic characteristics that are found within the leader [20].

trategic leadership can be marked as a source of creativity and innovation that is connected to the individuals' capabilities, creativity, and cognitive skills and accompanied by balance and practice which gives the organization an ability to achieve strategic goals [4].

\section{Problem Formulation}

The influential factors that have the ability to effect organization's reach of its gals can be summarized in skills and competences, culture, and organizational structure, such factors can be reached through developing the level of organizational commitment among employees as an

Independent Variable approach to develop the final outcome reaching to excellence and performance [18] [2]; [10]; [23]. From that point, the current study seeks to examine the impact of strategic leadership on organizational commitment within Islamic banks in Kuwait.

\subsection{Objectives and Hypotheses}

Current study developed the previous aim through utilizing the achievement of a set of objectives which were:

- Identify the core meaning of strategic leadership

- Connect between strategic leadership an organizational commitment.

- Highlight the relationship between strategic leadership and organizational commitment through understanding its influence on job satisfaction, turnover and organizational citizenship behavior which leads to organizational commitment.

Below model represented the relationship between variables from which hypotheses if study were derived:

\section{Dependent Variable}

\section{Dimensions of Strategic Leadership}

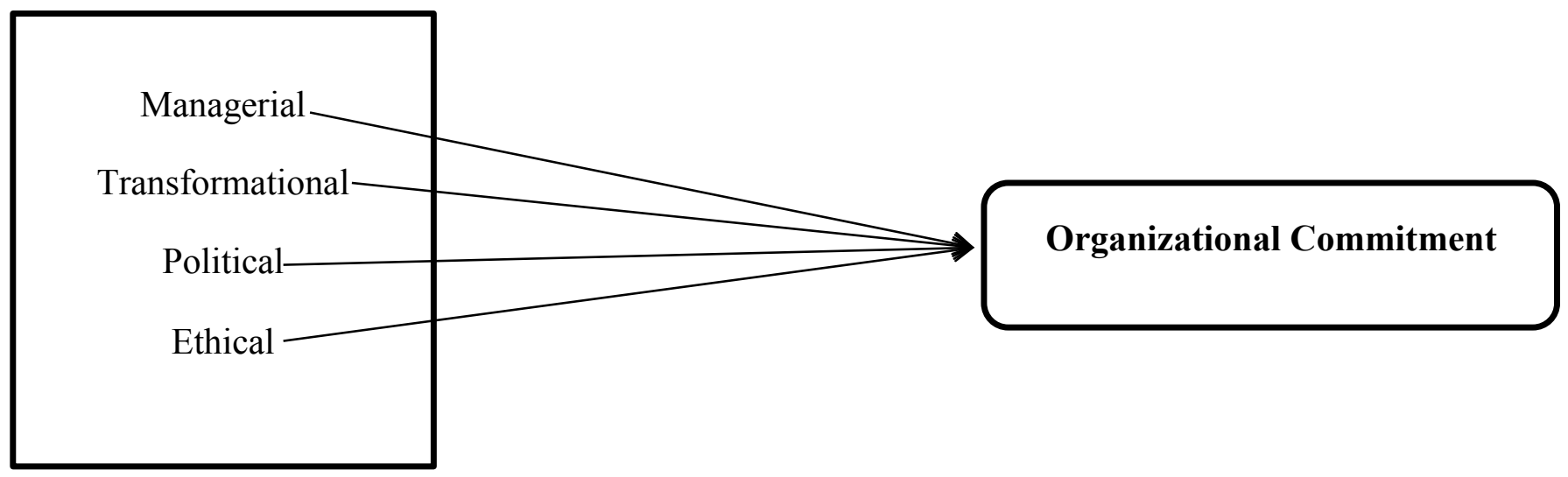

Figure (1): Study Model (Zahrani, 2018)

\subsection{Hypotheses Development}

Strategic leadership has the ability to influence organizational commitment by looking at the components of strategic leadership, which include defining strategic direction, exploiting competencies, developing human capital, stimulating the organization's culture, promoting ethical practices and setting controls the strategy.
That is, the strategic leadership with all its components focuses on the human element in the organization by working to exploit, maintain and develop the core competencies and competencies, which would increase the capabilities of working individuals and thus increase their benefit from the organization [5]. 
In general, the principle of strategic leadership starts from the people so that the strategic leaders provide a clear vision to direct the work in the right path that is consistent with the goals and objectives, and these leaders are aware of the need to create balance between organizational system and human resources, this creates enough space to focus and deal with the main issues affecting the organization. Strategic leaders continue to focus on the human side more than the institutional and analytical side, as is evident in modern employee-focused organizations [17].

On the concept of strategic leadership and organizational commitment; it was said that strategic leadership can help develop organizational commitment through the fact that strategic rationalizing the individuals' behavior, mobilizing their efforts, developing their abilities, coordinating their skills, organizing their issues, in addition to directing them towards realizing the desired goals and objectives [6].

Managerial influence of strategic leaders, they argued that strategic leadership can identify, from leaders' senior level, the sequence of events that may take place and monitor closely the application process, in addition to diagnose the factors that prevent the efficient application of strategy through the enhancement of a wide formal and informal strategic plans in the organization [28]. Strategic leaders also contribute to preparing the foundation of an organizational culture that encourages individuals in the organization to adapt to the strategy according to the highest acceptable levels of application (cultural change).

Strategic leadership also helps to keep the organization respondent to changing events (resilient) through the prediction of early opportunities and the creation of new ideas. This can be achieved through empowering individuals, especially those who have the desire to develop a new skill, practices, and better performance, and those who are willing to adapt to developments that leads new capabilities through coping in an efficient way with change of customers' needs and the complex competitive environment [3].

Strategic leaders could insert ethical conducts in the organizations by making themselves a role model for other working individuals, and urging others to make decisions with ethical dimensions [8]. Strategic leader also contributes to encouraging the creation of ethical programs by supporting the management to encourage ethical behavior in the organization [27]. In addition, strategic leadership provides support in dealing with unethical behavior based on early predictions and put a limit to any unethical conduct that may take place in the organization. Such argument was supported stating that strategic leader has the ability to support the creation of organizational citizenship behavior (OCB) and social responsibility through adopting the following practices [16]:

- Kind interaction with individuals.

- Supply individuals with a safe workplace.

- Adopt measures that are able to protect the environment

- Take part in social issues.

- Decrease unemployment and give chances to challenged individuals.

- Support all charity initiatives

Transformational strategic leader is always looking for potential followers' needs and motivations to satisfy the higher needs and their motives [11]; [25], [29] and [22] also added that transformational strategic leader respects the personality of their followers so that transformational leadership results in a relationship of motivation and mutual transcendence that transforms his followers into leaders by supporting the efforts of initiatives and making the changes needed to realize the future vision of organization more efficiently and effectively [9].

The political scene is one of the important aspects when trying to influence the higher centers of the organization and persuade it to change and amend some of its orientations, and here we must take into account the timing of the attempts to influence [26]. The political scene is also considered generalized when exercising influence on people from outside the institution, and because the state of ambiguity, uncertainty, and restricted resources determine the nature of the interaction between the organization and its surrounding environment, the political dimension plays an active role in influencing the organizational commitment by influencing interactive relationships With external entities affecting the work of the organization [19].

Based on above argument, researcher developed the following set of hypotheses:

\section{Main hypothesis:} Strategic leadership positively influences
organizational commitment 


\section{Sub-Hypotheses:}

H1: Managerial dimension of strategic leadership positively influences organizational commitment

H2: Transformational dimension of strategic leadership positively influences organizational commitment

H3: Political dimension of strategic leadership positively influences organizational commitment

H4: Ethical dimension of strategic leadership positively influences organizational commitment

\section{Methods}

Quantitative approach was adopted in order to realize aim of current study. A questionnaire was distributed on study sample which was built on liker 5 scale. The questionnaire consisted of 2 parts, the $1^{\text {st }}$ presented sample's demographics, while the $2^{\text {nd }}$ section presented statement related to study including dimensions of strategic leadership
(Managerial, Transformational, Political and Ethical).

The study population consists of the (5685) administrators working in the Kuwaiti Islamic banks (http://www.kibs.edu.kw/bayanati). Researcher contacted HRD within each bank and an online questionnaire was distributed on them in order from them to distribute it on the participants. The researcher made sure that volunteering participants were aware of study aim and objectives, and at the same time participants were aware of their rights in the participation process which included their right to be exposed of the reached results and their right to withdraw from participation whenever they feel like it.

A proportional stratified random sample of (360) administrators were taken - [24] - after application process, researcher was able to retrieve (273) valid questionnaires for analysis, which indicated a response rate of $(78.8 \%)$ as statistically accepted. Please see table 1 below:

*Table (1): Population and sample of study

\begin{tabular}{|c|c|c|c|}
\hline Bank & Number & Sample & $\begin{array}{c}\text { Retrieved } \\
\text { Sample }\end{array}$ \\
\hline Ahli United Bank & 828 & 52 & 48 \\
\hline Boubyan Bank & 1278 & 81 & 55 \\
\hline Kuwait Finance House & 2530 & 160 & 117 \\
\hline Kuwait International Bank & 703 & 45 & 38 \\
\hline Warba Bank & 346 & 22 & 15 \\
\hline Total & $\mathbf{5 6 8 5}$ & $\mathbf{3 6 0}$ & $\mathbf{2 7 3}$ \\
\hline
\end{tabular}

*Source: (http://www.kibs.edu.kw/bayanati)

In order to test the consistency of study tool, Cronbach Alpha was used and alpha value scored 0.88 which was greater than
0.60 which stated the consistency of study tool.

\section{Analysis and Discussion}

\subsection{Demographics}

Table (2): Sample characteristics according to demographics

Gender

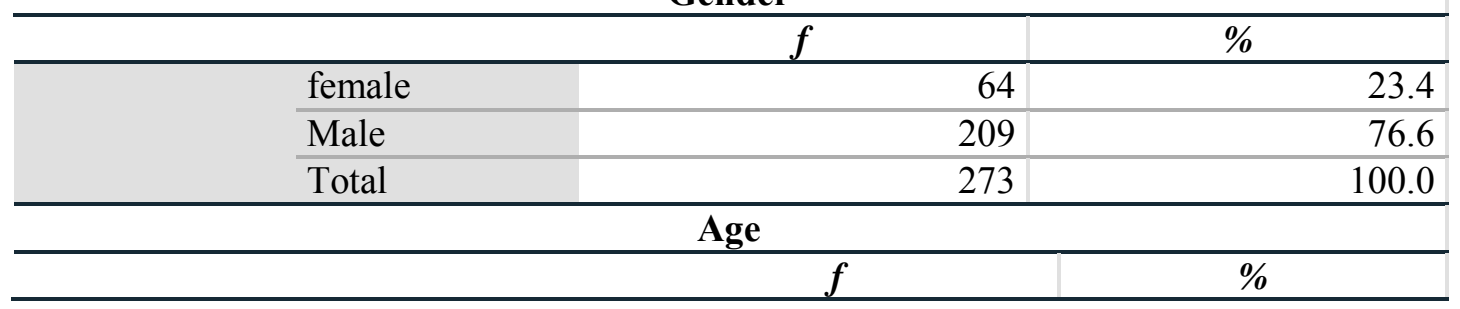




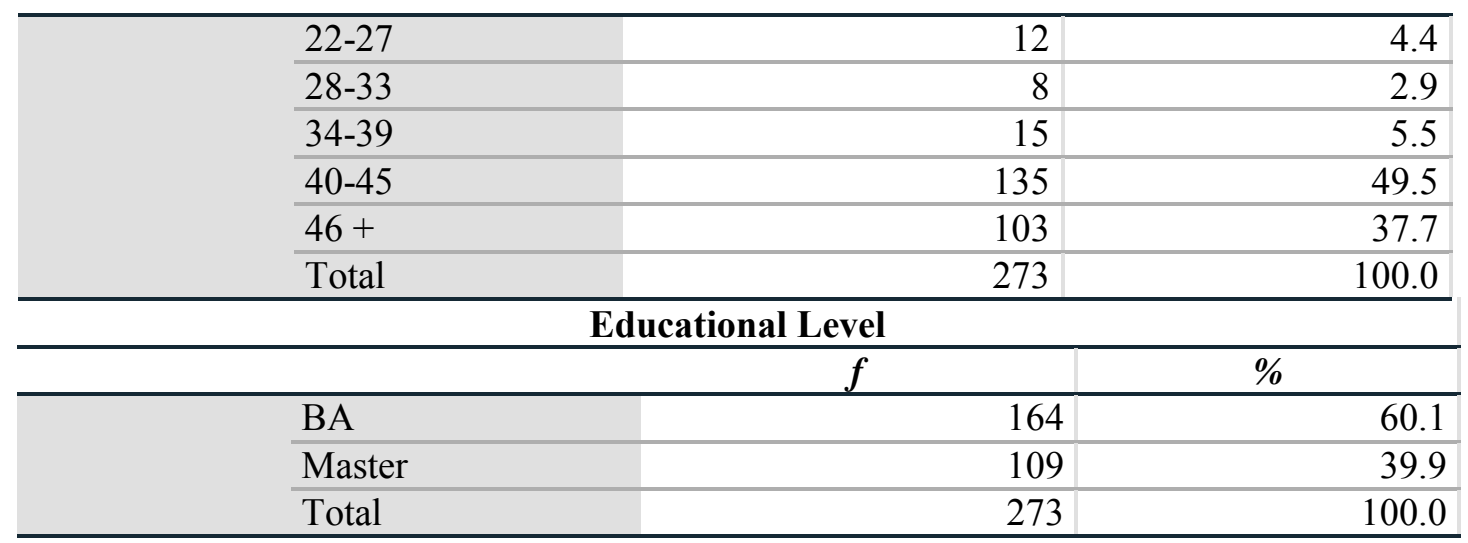

In table (2) above, sample properties according to respondents' demographics was calculated; results indicated that respondents to questionnaire mainly were males forming $76.6 \%$ of total sample compared to females who formed only $23.4 \%$ of the sample. As for the age range, it appeared that majority of sample was within age range of 40-45 years old forming $49.5 \%$ of the sample compared to least age range of 28-33 years old who formed only $2.9 \%$ of the sample. As for educational level, respondents holding BA degree formed $60.1 \%$ of the sample while MA degree holders formed 39.9\% of the sample.

\subsection{Questionnaire Analysis}

\section{Table 2. Questionnaire analysis}

\begin{tabular}{|c|c|c|}
\hline \multicolumn{3}{|l|}{ Strategic Leadership } \\
\hline \multicolumn{3}{|l|}{ Managerial } \\
\hline & Mean & $\begin{array}{c}\text { Std. } \\
\text { Deviation }\end{array}$ \\
\hline $\begin{array}{l}\text { There is a need to employ and invest various capabilities to fulfill } \\
\text { different roles }\end{array}$ & 4.33 & .471 \\
\hline $\begin{array}{l}\text { The managerial aspect promotes rationality and decision-making } \\
\text { between individuals, leaders and management }\end{array}$ & 4.33 & .471 \\
\hline $\begin{array}{l}\text { Usually, the management seeks to control and encourage the } \\
\text { observance of rules, setting goals, and adhering to them }\end{array}$ & 4.21 & .722 \\
\hline $\begin{array}{l}\text { The managerial dimension values the stability and depends on the law } \\
\text { in carrying out the work }\end{array}$ & 4.14 & .690 \\
\hline $\begin{array}{l}\text { Leadership and management meet to maintain proper functioning, } \\
\text { organizational justice and the achievement of the set goals }\end{array}$ & 4.72 & .451 \\
\hline \multicolumn{3}{|l|}{ Transformational } \\
\hline The transformative leader focuses on the needs of the subordinate & 4.16 & .593 \\
\hline $\begin{array}{l}\text { Transformational leadership adopts the foundations of satisfying } \\
\text { workers' needs and motives }\end{array}$ & 3.94 & .710 \\
\hline $\begin{array}{l}\text { Transformational leadership creates a relationship of motivation and } \\
\text { mutual transcendence that turns followers into leaders }\end{array}$ & 4.10 & .646 \\
\hline $\begin{array}{l}\text { Transformational leadership shapes the strategic leader's business and } \\
\text { helps him to do his part }\end{array}$ & 4.27 & .445 \\
\hline $\begin{array}{l}\text { Through transformational leadership, strategic leadership works to } \\
\text { build a vision based on looking ahead, with opportunities and threats }\end{array}$ & 4.15 & .586 \\
\hline \multicolumn{3}{|l|}{ Political } \\
\hline $\begin{array}{l}\text { The political scene is one of the most exciting aspects of the } \\
\text { organization's senior positions }\end{array}$ & 3.46 & 1.050 \\
\hline $\begin{array}{l}\text { The political scene persuades the organization to change or amend } \\
\text { some of its directions }\end{array}$ & 3.55 & .902 \\
\hline
\end{tabular}




\begin{tabular}{|c|c|c|}
\hline $\begin{array}{l}\text { The political situation affects the attitudes of individuals outside the } \\
\text { organization }\end{array}$ & 3.85 & 679 \\
\hline $\begin{array}{l}\text { The political dimension contributes to creating and building strategic } \\
\text { partnerships and alliances that contribute to strengthening workers and } \\
\text { developing their capabilities and productivity. }\end{array}$ & 3.63 & .736 \\
\hline $\begin{array}{l}\text { Strategic leadership through the political dimension works to build } \\
\text { strong relationships between individuals inside and outside the } \\
\text { organization, which would provide a stable and effective environment }\end{array}$ & 3.55 & .821 \\
\hline \multicolumn{3}{|l|}{ Ethical } \\
\hline Strategic leadership is built on ethics & 4.26 & 691 \\
\hline $\begin{array}{l}\text { Formulating the strategy, implementing it and evaluating its decisions } \\
\text { carries with it ethical behavior }\end{array}$ & 4.04 & .721 \\
\hline $\begin{array}{l}\text { The strategic leader is responsible first and foremost for establishing } \\
\text { ethical principles within the organization }\end{array}$ & 4.08 & .619 \\
\hline $\begin{array}{l}\text { The more ethics proves to be within the organization, the more efficient } \\
\text { it is to strengthen its relationship with employees }\end{array}$ & 4.46 & .606 \\
\hline $\begin{array}{l}\text { Ethics in strategic leadership creates a team spirit within the } \\
\text { organization and supports the foundations of justice and equality } \\
\text { among the working individuals }\end{array}$ & 4.19 & .498 \\
\hline \multicolumn{3}{|l|}{ Organizational Commitment } \\
\hline $\begin{array}{l}\text { Strategic leadership strengthens commitment by focusing on the } \\
\text { foundations of justice and equality among working people }\end{array}$ & 3.96 & .520 \\
\hline $\begin{array}{l}\text { Organizational commitment is created by adopting leadership bases } \\
\text { that fulfill business ethics frameworks }\end{array}$ & 4.01 & .326 \\
\hline $\begin{array}{l}\text { Strategic leadership forms the general basis for organizational } \\
\text { commitment by developing the relationship of working people with } \\
\text { their management and leadership }\end{array}$ & 3.95 & .631 \\
\hline $\begin{array}{l}\text { Organizational commitment is one of the results of strategic leadership } \\
\text { as it contributes to creating an attractive environment for working } \\
\text { among individuals }\end{array}$ & 3.90 & .910 \\
\hline $\begin{array}{l}\text { Usually individuals are more organizationally committed when } \\
\text { working under effective strategic leadership }\end{array}$ & 4.54 & .499 \\
\hline $\begin{array}{l}\text { Strategic leadership encourages empowerment, which increases the } \\
\text { level of organizational commitment }\end{array}$ & 4.33 & .471 \\
\hline
\end{tabular}

Table (2) presented respondents' answers to questionnaire statements based on likert 5 scale (1 strongly disagree, 2 disagree, 3 neutral, 4 agree, 5 strongly agree). Analysis indicated that respondent had positive attitudes towards statements of questionnaire given that all mean of statements were higher than mean of scale 3.00 which is statistically a positive result. From table above, it can be read that the most positively answered statement was articulated "Usually individuals are more organizationally committed when working under effective strategic leadership" scoring a mean of 4.54/5.00. On the other hand, the least positively answered statements was articulated "The political scene is one of the most exciting aspects of the organization's senior positions" scoring a mean of $3.46 / 5.00$.

In table (3) below, mean and standard deviation was calculated for variables of study, table showed that respondents held positive attitudes towards variables as they all scored higher than mean of scale 3.00 which was seen as statistically positive.

Table (4): Variables' Descriptive Statistics

\begin{tabular}{lcc}
\hline & Mean & Std. Deviation \\
\hline Strategic Leadership & & \\
\hline
\end{tabular}




\begin{tabular}{l|l|l}
\hline Managerial & 4.3465 & .30522 \\
\hline Transformational & 4.1253 & .43214 \\
\hline Political & 3.6088 & .65028 \\
\hline Ethical & 4.2051 & .52620 \\
\hline Organizational Commitment & 4.1160 & .35352 \\
\hline
\end{tabular}

4.3 Hypotheses Testing Main hypothesis:
Strategic leadership positively influences organizational commitment

Table (5): Testing main hypothesis

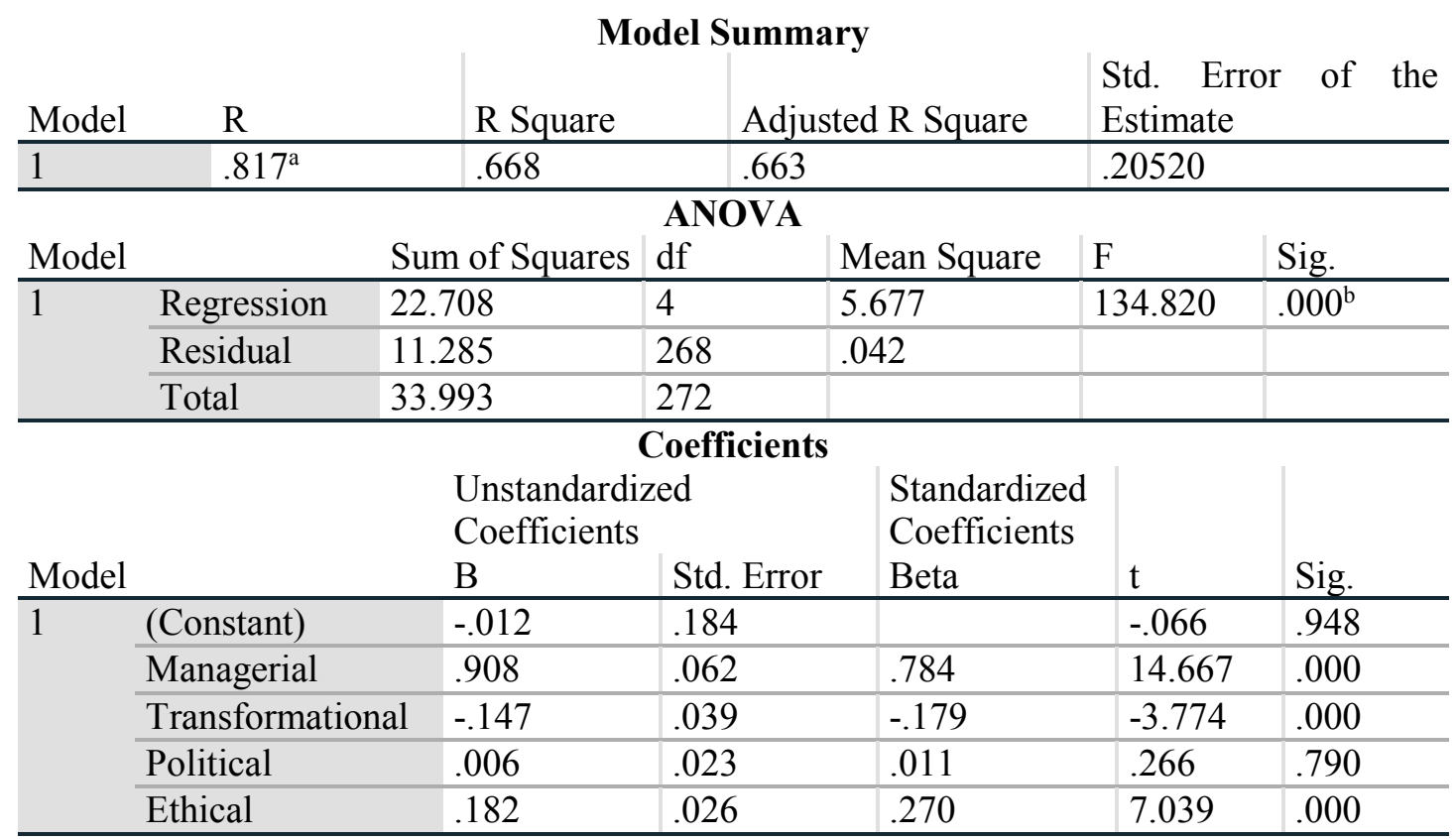

Depending on multiple Regression; $\mathrm{R}=0.817$ reflected high significant impact, and $\mathrm{r}^{2}=0.668$ reflected $66.8 \%$ of the variance in the dependent variable was explained by the independent variable. Also, $F$ value $=134.82$ was significant at 0.05 level H1: Managerial dimension of strategic leadership positively influences organizational commitment which means Strategic leadership positively influences organizational commitment

Sub-Hypotheses:

Table (6): Testing $1^{\text {st }}$ hypothesis

\begin{tabular}{|c|c|c|c|c|c|c|c|}
\hline \multicolumn{8}{|c|}{ Model Summary } \\
\hline Model & $\mathrm{R}$ & R Square & & \multicolumn{2}{|c|}{ Adjusted R Square } & \multicolumn{2}{|c|}{$\begin{array}{l}\text { Std. Error of the } \\
\text { Estimate }\end{array}$} \\
\hline 1 & $.769^{\mathrm{a}}$ & .591 & & .589 & & .22654 & \\
\hline \multicolumn{8}{|c|}{ ANOVA } \\
\hline \multicolumn{2}{|l|}{ Model } & Sum of Squares & df & & Mean Square & $\mathrm{F}$ & Sig. \\
\hline \multirow[t]{3}{*}{1} & Regression & 20.086 & 1 & & 20.086 & 391.393 & $.000^{\mathrm{b}}$ \\
\hline & Residual & 13.908 & 271 & & .051 & & \\
\hline & Total & 33.993 & 272 & & & & \\
\hline
\end{tabular}




\begin{tabular}{|c|c|c|c|c|c|c|}
\hline \multirow[b]{2}{*}{ Model } & & \multicolumn{2}{|c|}{ Unstandardized Coefficients } & \multirow{2}{*}{$\begin{array}{l}\text { Standardized } \\
\text { Coefficients } \\
\text { Beta }\end{array}$} & \multirow[b]{2}{*}{$\mathrm{t}$} & \multirow[b]{2}{*}{ Sig. } \\
\hline & & B & Std. Error & & & \\
\hline \multirow[t]{2}{*}{1} & (Constant) & .246 & .196 & & 1.255 & .210 \\
\hline & Managerial & .890 & .045 & .769 & 19.784 & .000 \\
\hline
\end{tabular}

Utilizing linear Regression, $r=0.769$ reflected a high significant impact as well as $r^{2}=0.591$ reflected $59.1 \%$ of the variance in the dependent variable was explained by the independent variable. $\mathrm{F}$ value $=391.393$ was significant at 0.05 level which means Managerial dimension of strategic leadership positively influences organizational commitment.

H2: Transformational dimension of strategic leadership positively influences organizational commitment

\section{Table (7): Testing $2^{\text {nd }}$ hypothesis}

\begin{tabular}{|c|c|c|c|c|c|c|}
\hline \multicolumn{7}{|c|}{ Model Summary } \\
\hline Model & $\mathrm{R}$ & R Square & \multicolumn{2}{|c|}{ Adjusted R Square } & \multicolumn{2}{|c|}{$\begin{array}{l}\text { Std. Error of the } \\
\text { Estimate }\end{array}$} \\
\hline 1 & $.410^{\mathrm{a}}$ & .168 & .165 & & .32305 & \\
\hline \multicolumn{7}{|c|}{ ANOVA } \\
\hline Model & & Sum of Squares & $\mathrm{df}$ & Mean Square & $\mathrm{F}$ & Sig. \\
\hline \multirow[t]{3}{*}{1} & Regression & 5.712 & 1 & 5.712 & 54.729 & $.000^{\mathrm{b}}$ \\
\hline & Residual & 28.282 & 271 & .104 & & \\
\hline & Total & 33.993 & 272 & & & \\
\hline \multicolumn{7}{|c|}{ Coefficients } \\
\hline \multirow{2}{*}{\multicolumn{7}{|c|}{$\begin{array}{l}\text { Unstandardized } \\
\text { Coefficients }\end{array}$}} \\
\hline & & & & Coefficients & & \\
\hline Model & & B & Std. Error & Beta & $\mathrm{t}$ & Sig. \\
\hline \multirow[t]{2}{*}{1} & (Constant) & 2.733 & .188 & & 14.535 & .000 \\
\hline & Transformationa & .335 & .045 & .410 & 7.398 & .000 \\
\hline
\end{tabular}

Also linear Regression was used to test $2^{\text {nd }}$ hypothesis, results indicated that $r=0.41$ reflected medium significant impact and $\mathrm{r}^{2}$ $=0.168$ reflected $16.8 \%$ of the variance in the dependent variable was explained by the independent variable. With an $\mathrm{F}$ value $=$ 54.729 was significant at 0.05 level, it was confirmed that Transformational

Table (8): Testing $3^{\text {rd }}$ hypothesis

\begin{abstract}
dimension of strategic leadership positively influences organizational commitment.
H3: Political dimension of strategic leadership positively influences organizational commitment
\end{abstract}

Model Summary

\begin{tabular}{|c|c|c|c|c|c|c|c|}
\hline \multirow[b]{2}{*}{ Model } & \multicolumn{5}{|c|}{ Model Summary } & \multirow{2}{*}{\multicolumn{2}{|c|}{$\begin{array}{l}\text { Std. Error of the } \\
\text { Estimate }\end{array}$}} \\
\hline & $\mathrm{R}$ & \multicolumn{2}{|l|}{ R Square } & \multicolumn{2}{|c|}{ Adjusted R Square } & & \\
\hline 1 & $.447^{\mathrm{a}}$ & .199 & & \multicolumn{2}{|c|}{.196} & \multicolumn{2}{|c|}{.31690} \\
\hline \multicolumn{8}{|c|}{ ANOVA } \\
\hline Model & & Sum of Squares & df & & Mean Square & $\mathrm{F}$ & Sig. \\
\hline \multirow[t]{3}{*}{1} & Regression & 6.778 & 1 & & 6.778 & 67.494 & $.000^{\mathrm{b}}$ \\
\hline & Residual & 27.215 & 271 & & .100 & & \\
\hline & Total & 33.993 & 272 & & & & \\
\hline \multicolumn{8}{|c|}{ Coefficients } \\
\hline Model & & Unstandardized C & effic & ients & $\begin{array}{l}\text { Standardized } \\
\text { Coefficients }\end{array}$ & $\mathrm{t}$ & Sig. \\
\hline
\end{tabular}




\begin{tabular}{ll|l|l|l|l|l}
\multicolumn{1}{c}{} & B & Std. Error & Beta & & \\
\hline 1 & (Constant) & 3.240 & .108 & & 29.904 & .000 \\
\cline { 2 - 7 } & Political & .243 & .030 & .447 & 8.215 & .000 \\
\hline
\end{tabular}

Linear Regression was in testing this hypothesis indicated that $\mathrm{r}=0.447$ and reflected medium significant impact, while $\mathrm{r}^{2}=0.199$ reflected $19.9 \%$ of the variance in the dependent variable was explained by the independent variable. As the $\mathrm{F}$ value $=67.494$ was significant at 0.05 level, it mean
Political dimension of strategic leadership positively influences organizational commitment

H4: Ethical dimension of strategic leadership positively influences organizational commitment

\section{Table (9): Testing $4^{\text {th }}$ hypothesis}

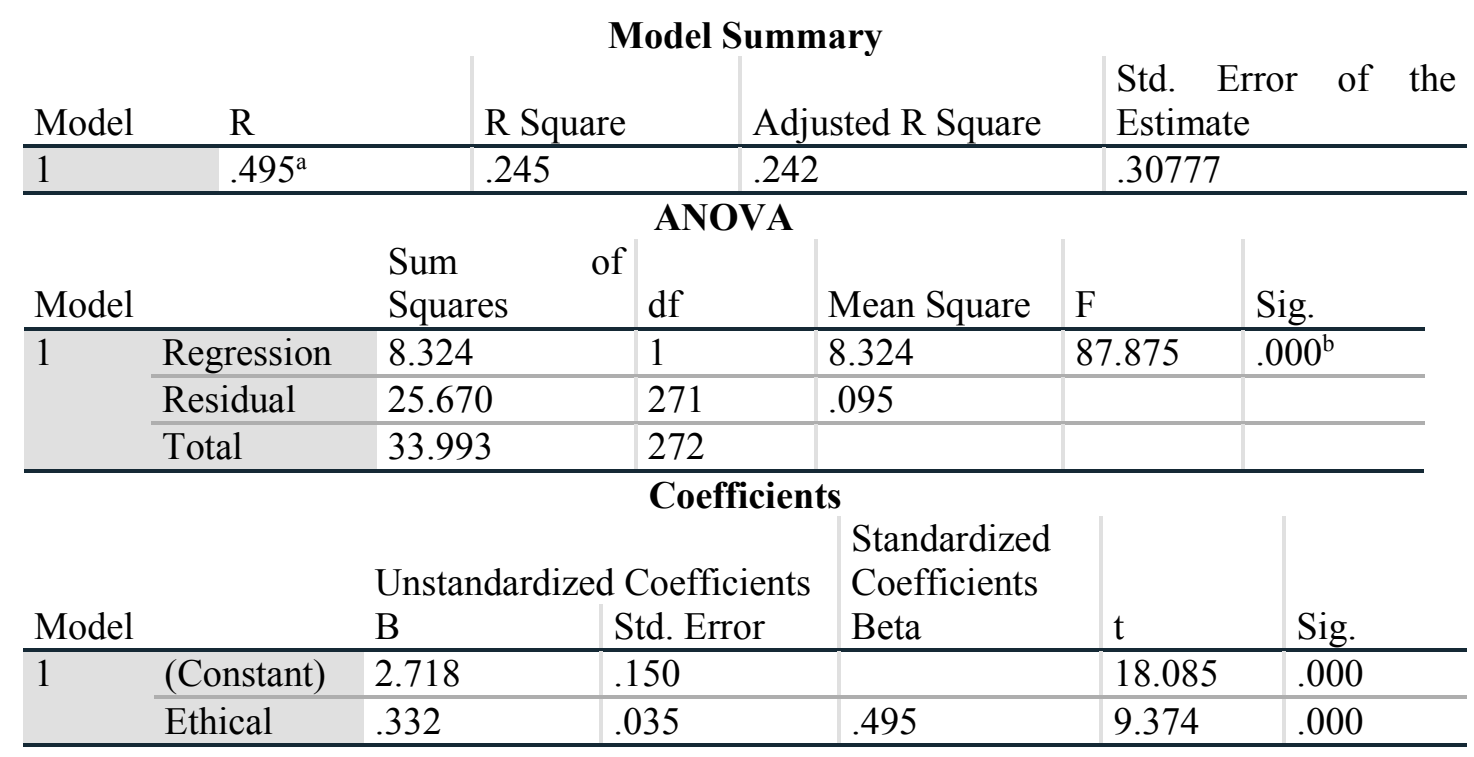

Linear Regression was employed in testing $4^{\text {th }}$ hypothesis, with $\mathrm{r}=0.495$ reflected medium significant impact and $\mathrm{r}^{2}=0.245$ reflected $24.5 \%$ variance in the dependent variable was explained by the independent variable, and $F$ value $=87.875$ was significant at 0.05 level, the hypothesis was accepted and Ethical dimension of strategic leadership positively influences organizational commitment.

\section{Discussion}

Current study aimed at examining how strategic leadership could be influential on organizational commitment within Islamic banks in Kuwait. Through adopting the quantitative approach and distributing (273) questionnaire on individuals within Islamic banks in Kuwait; results indicated the following:

- Respondents had high level of awareness regarding strategic leadership and its impact on organizational commitment given that all respondents had positive attitudes towards variables of study.

- With (66.8\%) of the variance in the dependent variable was explained by the independent variable; it appeared through study that "Strategic leadership positively influences organizational commitment"

- Scoring a variance of $\mathbf{( 5 9 . 1 \% )}$ of the relationship between dependent and independent variables; study indicated that "Managerial dimension of strategic leadership positively influences organizational commitment".

- Coming in the $2^{\text {nd }}$ rank and with a variance of $(\mathbf{2 4 . 5 \% )}$ it appeared that "Ethical dimension of strategic leadership positively influences organizational commitment".

- Transformational aspect of strategic leadership scored a variance of (16.8\%) which explained the result of "Transformational dimension of strategic 


\section{leadership positively influences organizational commitment".}

- Scoring a variance of (19.9\%), results of study indicated that "Political dimension of strategic leadership positively influences organizational commitment".

As it appeared from results, study was able to realize that strategic leadership is a type of a leadership that has the ability to influence organizational commitment giving the fact that it is a process used through the leader so as to realize a vivid and comprehensive strategic mission by impacting the organization's culture, allocating resources, directing through policies, and achieving harmony within a complicated and highly assured universal environment in order to diagnose threats and chances.

\section{Managerial dimensions of Strategic Leadership}

Current study has proven that strategic leadership is of great importance as it helps to develop and create sense within the organization and create a state of integration between senior management and individuals working in connection with the organization's goal and vision, and strategic leadership contributes to ensuring the highest levels of satisfaction within the work environment which would increase the level of employee satisfaction with their work and thus increase their organizational commitment rhyming with what [28].

Current study's results matched [3] who arguing that strategic leadership has the ability to develop human capital by focusing on individuals who possess skills and knowledge that contribute to increasing the economic value of the organization, and the strategic management considers working individuals as representing a capital resource that needs investment. The effects of strategic leadership also appear in developing organizational commitment by maintaining an effective organizational culture by providing solutions to external adjustment problems and internal integration problems. It means that strategic leadership has the ability to formulate a culture that prepares individuals with skills to face risks and chances within the external environment and at the same time increase the efficiency within the internal environment.

\section{Strategic Leadership and Ethics}

The study also demonstrated that strategic leadership emphasizes the ethical practices that govern the process of interaction between working individuals on the one hand and the organization on the other hand by establishing the foundations and a collective monitoring system for individuals within the organization in order to maintain organizational activities or bring about a change in their patterns, and thus, maintaining a standard of ethical practices within the leadership of individuals contributes to achieving adaptation to environmental changes and finance, through that the strategic leader balances work and achieving results and adhering to ethics in dealing.

\section{Strategic Leadership in a Transformational Shape}

The study also proved that the transformational strategic leader turns individuals into leaders and then turns them into ethical agents in the process of transcending the motives, inclinations or personal needs of the organization. The transformational dimension also constitutes the work of the strategic leader and helps him to carry out his role, especially in an environment characterized by this agreed with [25]; [11]; [9]; [29] and [22] that indicated the main purpose of strategic leadership is to bring about change and transform the organizational environment into a more stimulating environment and to enhance achievement and outstanding performance. Study confirmed that strategic leadership dimensions and especially the transformational aspect of strategic leadership can help in supporting leaders with the ability to formulate vision and mission through anticipating the future along with its opportunities and threats, in addition to providing the organizational environment with the stimulants stimulates that motivates individuals to employ their skills, knowledge and abilities for the service of the organization.

\section{Political Scene from Strategic Leadership Perspective}

The study proved that the political aspect of strategic leadership has an effective impact on the organizational commitment by trying to push the organization to change and push the working individuals to accept change based on the changes of the surrounding environment. This is in agreement with the study by [26] and [19] when it was confirmed that the political aspect of strategic leadership contributes to the ability to persuade, build partnerships and strategic alliances, reward behavior, compromise, negotiate, deal with 
resistance, use power and influence effectively in a timely manner. Moreover, the strategic leadership through the political dimension - works to build good relationships between individuals and groups within the organization with the aim of providing a stable and effective political environment and taking advantage of the opportunities available by building alliances and partnerships that can serve the achievement of the organization's strategic goals.

Generally speaking, this research study can be important to leaders in terms of guiding them and supporting their plans to develop an organizational environment that supports working individuals and lead them to achieve the desired goal as according to the plan, from that sense, and launching from the traits and specifications of a strategic leader, there would be a chance for individuals to trust their leader and look at them as a role model which helps in building the sense of commitment in them, and distribute it on other individuals and pave the way for a general organizational commitment.

\section{Conclusion and Recommendations}

In investigating the influence of strategic leadership on organizational commitment; it was proved that strategic leadership can influence employees' organizational commitment through influencing their attitude towards their job and work environment. This can happen through strategic leadership that has the ability to connect between individuals, let them see the goal they need to reach in unity, develop their sense of achievement and support their moral values through their connection with the leader. Managerial aspect appeared to be the prevailing side which controls strategic leadership as it has the ability to motivate creativity and innovation which depends largely - on the skills and creativity of strategic leaders and their upcoming vision of event. It also plays a significant role in implementing organizational strategies depending on a choice of practices that could realize a balance among needs and desires.

Thus, the strategic leadership supports working individuals and gives them the capability to share and learn knowledge, information, and responsibility among each other, and provides them with optimum motives to develop their skills such as creativity, innovation and communication skills. This matter would greatly contribute to developing a sense of organizational commitment among working individuals by influencing knowledge skills, social intelligence, and behavior. It means that a strategic leadership has the ability to develop organizational commitment through building a supporting environment for individuals working in team, gain their trust, motivate them and distribute moral values among them. When this take place, it can be said that a strategic leadership managed to create commitment from individuals towards their organization.

\section{Based on above results and conclusion; current} study recommended:

- Promoting strategic leadership practices by investing in human capital and focusing on continuous learning and improvement.

- Promote active organizational learning through focusing on the relationship between leaders and employees.

- Conducting more research and studies on the nature of the correlational relationship between the different dimensions of strategic leadership and both the culture of organizational learning and developmental performance, using a more diverse group of quantitative or qualitative and mixed research approaches in order to develop new models for the relationship of strategic leadership with organizational performance and working individuals.

- As a future direction, it is recommended to examine the role of strategic leadership in developing problem solving skills among individuals through the moderating role of empowerment. 


\section{References}

[1] Afifah, N., \& Daud, I. Strategic Leadership Style and Commitment to Service Quality on Services Innovation in Local Enterprise Water Services. J. Mgt. Mkt. Review, pp. 143-148, Volume 3, No 3, 2018.

[2] Al-Zahrani, I. Strategic Leadership and Their Impact in the Development of Organizational Learning Capabilities: Study practice in the Umm Al Qura University, International Journal for Research in Education, Volume 42, No 2, 2018

[3] Azbari, M. E., Akbari, M., \& Chaijani, M. $H$. The effect of strategic leadership and empowerment on job satisfaction of the employees of University of Guilan. International Journal of Organizational Leadership, Volume 4, No 4, 2015.

[4] Bonau, S. Strategic Leadership, Commitment and Employee Motivation: what influences attitudes towards the workplace. Köz-gazdaság-Review of Economic Theory and Policy, Volume 14, No 4, 2019.

[5] Chanpoom, N., \& Intrawong, W. The Influence of Strategic Leadership and Organizational climate on Organizational Commitment of Savings Cooperative Employees, Thailand. in international academic multidisciplinary research conference in Vienna 2019.

[6] Dabas, H. F., \& Muslim, D. A. Strategic leadership competencies and their role in organizational agility Analytical Study in AsiaCell telecom Company. AL-Anbar University journal of Economic and Administration Sciences, Volume 12, No, 28, 2020.

[7] Dyer, G., \& Dyer, M. Strategic leadership for sustainability by higher education: the American College \& University Presidents' Climate Commitment. Journal of Cleaner Production, pp. 111-116, Volume 140, 2017.

[8] Ebrahimpour Azbari, M., Akbari, M., \& Hooshmand Chaijani, M. The effect of strategic leadership and empowerment on job satisfaction of the employees of University of Guilan. International Journal of Organizational Leadership, pp. 453-464, Volume 4, 2015.
[9] Gordon, R. Strategic transformational organizational leadership. In Encyclopedia of Strategic Leadership and Management, pp. 1667-1684. IGI Global, 2017

[10] Irtaimeh, H. J. Impact of Strategic Leadership Competencies on Enhancing Core Competencies in Organizations: Applied Study on Al-Manaseer Group for Industrial \& Trading. Modern Applied Science, pp. 169-180, Volume 12, 11, 2018.

[11] Kazmi, S. A. Z., Naaranoja, M., \& Kytölä, J. Integrating strategic thinking and transformational leadership for NPD idea support process, Volume 8, 2018

[12] Keskes, I. Relationship between leadership styles and dimensions of employee organizational commitment: A critical review and discussion of future directions. Intangible Capital, pp. 26-51, Volume 10, No 1, 2014.

[13] Lee, J. Y., \& Welliver, M. C. The role of strategic leadership for learning on the relationship between training opportunities and salesperson job performance and commitment. European Journal of Training and Development, Volume 12, 2018

[14] Naim, M. F., \& Lenka, U. Organizational learning and Gen $Y$ employees' affective commitment: The mediating role of competency development and moderating role of strategic leadership. Journal of Management and Organization, pp. 815-831, Volume 26, No 5, 2020

[15] Nakir, M., Djati, P., \& Arafah, W. The Effect of Strategic Leadership and Self-Efficacy on Organizational Commitment and Its Implication on Performance Defense Researchers. In International Conference on Management, Accounting, and Economy (pp. 248-251). Atlantis Press, 2020

[16] Ngamau, P. N. Influence of strategic partnerships on performance of insurance companies in Kenya (Doctoral dissertation, University of Nairobi), 2015

[17] Noor, J. The Factors of Strategic Leadership on Commitment: An Empirical Banking in Indonesia. International Research Journal of Business Studies, Volume 6, No 3, 2015

[18] Norzailan, Z., Othman, R. B., \& Ishizaki, H. Strategic leadership 
competencies: what is it and how to develop it?. Industrial and Commercial Training, pp. 2016-219, Volume 5, 2016

[19] Okigbo, C., \& Onoja, B. Strategic political communication in Africa. In Political communication in Africa (pp. 63-80). Springer, Cham. 2017

[20] Olwan, A. A., Irtaimeh, H. J. A., \& Al-Lozi, M. Strategic Leadership Competencies and its Relationship on Achieving Organizational Commitment: A Theoretical Study. Journal of Business \& Management (COES\&RJ-JBM), pp. 34-57, Volume 7, No. 1, 2019

[21] Omar, N. Influence Of Strategic Leadership On Performance Of Manufacturing Companies In Kenya: A Case Study Of Zenko Kenya Limited (Doctoral dissertation, MUA), 2018

[22] Phornlaphatrachakorn, K. Effects of Transformational Leadership, Organisational Learning and Technological Innovation on Strategic Management Accounting in Thailand's Financial Institutions. AJBA, pp. 165-188, Volume 12, No. 1, 2019

[23] Schutte, N., \& Barkhuizen, N. The development of a strategic leadership competency measure for public sector leaders-a pilot study. Development, pp. 2129. Volume 2, No 3, 2016

[24] Sekaran, U. Research methods for business: A skill building approach. John Wiley \& Sons, 2006

$\begin{array}{lr}\text { [25] Sharma, } & \text { M. Radical } \\ \text { transformational leadership: } & \text { Strategic }\end{array}$ action for change agents. North Atlantic Books, 2017

[26] Tikkanen, H. Strategic Leadership and Organizational Transformation: A Leadership History of the British Royal Navy during the 'Fisher Era'19041919. JYU dissertations. 2020

[27] Waris, M., Khan, A., Ismail, I., Adeleke, A. Q., \& Panigrahi, S. Impact of leadership qualities on employee commitment in multi-project-based organizations. In IOP Conference Series: Earth and Environmental Science, p. 012094, Volume140, No. 1, 2018

[28] Zehir, C., Sehitoglu, Y., \& Erdogan, E. The effect of leadership and supervisory commitment to organizational performance. Procedia-Social and Behavioral Sciences, 207-216. Volume 58, 2012

[29] Zuraik, A. A strategic model for innovation leadership: Ambidextrous and transformational leadership within a supportive climate to foster innovation performance (Doctoral dissertation, Alliant International University), 2017

[30] Hossam Meshref, Predicting Loan Approval of Bank Direct Marketing Data Using Ensemble Machine Learning Algorithms, International Journal of Circuits, Systems and Signal Processing, pp. 914-922, Volume 14, 2020.

[31] Guannan Bao, Fanlei Zeng, Mingwei Wang, Study on Human Resource Allocation Efficiency Based on DEA Analysis, International Journal of Circuits, Systems and Signal Processing, pp. 826832, Volume 14, 2020.

\section{Creative Commons Attribution License 4.0 (Attribution 4.0 International, CC BY 4.0)}

This article is published under the terms of the Creative Commons Attribution License 4.0

https://creativecommons.org/licenses/by/4.0/deed.en_US 